\title{
PENDIDIKAN TENTANG KESADARAN HUKUM BAGI ANAK BERMASALAH HUKUM DI LAPAS
}

\author{
Arifin \\ Dosen STKIP 11 April Sumedang, Jl. Anggrek Situ No.19 Sumedang Kode Pos \\ 45323, Telp: 0261-202911, Hp: 081320208610, E-mail: \\ arifin_nurdinsyah@yahoo.co.id
}

\begin{abstract}
ABSTRAK
Permasalahan yang dihadapi dalam optimalisasi kualitas "Pendidikan bagi Anak Didik di Lapas Anak Tangerang" dewasa ini adalah terjadinya kontradiksi antara nilai-nilai harapan (das Sollen) dengan nilai-nilai realitas (das Sein), dan faktor dominan yang mempengaruhi kualitas "Pendidikan anak didik di Lapas Anak Tangerang", adalah faktor instrument input pendidikan. Studi kualitatif penelitian ini bertujuan untuk menemukan pola pendidikan yang sesuai dengan pendidikan kesadaran hukum bagi anak didik lembaga pemasyarakatan anak. Proses penelitian ini dilaksanakan berdasarkan metode kualitatif, yang bersifat natural, deskriptif, induktif, dan menemukan makna dari suatu fenomena. Hasil penelitian Kualifikasi Pendidik yang memiliki kepribadian beriman dan bertaqwa, ramah, penuh kelembutan, berperan sebagai orang tua, berwawasan luas, dan berempati, berdampak positif terhadap proses pembinaan; Perencanaan Pembinaan mengkombinasikan antara Top Down dengan Bottom Up; Pendekatan dan Metode Pembinaan yang mengkombinasikan model fungsionalis dan religious, melalui : keteladanan (contoh), pembiasaan dan latihan, penciptaan situasi yang kondusif, kedisiplinan, pelaksanakan ibadah secara mendalam, mendorong akselerasi proses pembinaan anak didik Lapas, Evaluasi Pendidikan di Lapas, perlu melibatkan peran anak didik, keluarga, dan masyarakat, sehingga berfungsi sebagai feed back terhadap peningkatan kualitas pembinaan di Lapas.

Kata kunci: pendidikan, kesadaran, hukum, anak.
\end{abstract}

\begin{abstract}
Problems faced in optimizing the quality of "Education for Learners in Tangerang correctional institution" today is the contradiction between the values of hope (das sollen) with the values of reality (das Sein), and the dominant factor affecting the quality of the "Education students in Tangerang correctional institution ", is a factor of the input instrument of education. Qualitative study, this study aims to find patterns of education in accordance with the legal awareness education for students penitentiary child. The research process was conducted based on the qualitative method, which is natural, descriptive, inductive, and discover the meaning of a phenomenon. Educator Qualifications research results that have a faithful and devoted personality, friendly, full of tenderness, acting as a parent, insightful, and empathy, positive impact on the development process; Development Planning combines the Bottom Up Top Down; Approach and method that combines coaching and religious functionalist models, through: the example (example), habituation and training, creation of favorable situation, discipline, implementing worship deeply, accelerate the process of coaching, Evaluation of Education in Prison, the need to involve the role students, families, and communities, thus serving as a feed back to the improvement of the quality of coaching in prison.
\end{abstract}

Keywords: education, awareness, law, child. 


\section{PENDAHULUAN}

A. Latar Belakang Masalah

Pendidikan nasional yang berakar pada kebudayaan bangsa Indonesia berdasarkan Pancasila dan UUD 1945, berfungsi mengembangkan kemampuan dan membentuk watak serta peradaban bangsa yang bermartabat dalam rangka mencerdaskan kehidupan bangsa, dan bertujuan untuk mengembangkan potensi peserta didik agar menjadi manusia yang beriman dan bertaqwa kepada Tuhan Yang Maha Esa, berakhlak mulia, sehat, berilmu, cakap, kreatif, mandiri, dan menjadi warga negara yang demokratis serta bertanggung jawab (UUSPN No 20 tahun 2003).

Sosok peserta didik yang dimaksud dalam tujuan pendidikan nasional tersebut, adalah merupakan potret kepribadian manusia utuh, dan bila di lihat dari sudut pandang pendidikan umum sebagaimana dinyatakan oleh Phenix (1964: 8) bahwa:

a complete person should be skilled in the use of speech, symbol, and gesture, factually well informed, capable of creating and appreciating objects of esthetic significance, endowed with a rich and diciplined life and relation to selft and others, able to make wise decisions and to judge between right and wrong, and possessed of integral out look.

Namun seiring dengan terjadinya krisis multidimensi yang dialami bangsa Indonesia, dimulai dari krisis di pasar uang, meluas ke krisis ekonomi, menyulut krisis politik dan moneter, menggemparkan krisis kepercayaan dan kelembagaan masyarakat (Achmad Sanusi, 1998 : 
26), telah berdampak juga terhadap masa depan anak-anak (peserta didik) Indonesia.

Komisi Nasional Perlindungan Anak Indonesia (2002 : 2) telah mencatat berbagai bentuk pelanggaran terhadap hak-hak anak. Angka pelanggaran terhadap hak-hak anak terdokumentasi dari tahun ke tahun terus meningkat. Sementara jaminan pemerintah dan perlindungan bagi anak-anak korban terus terabaikan. Khususnya perhatian terhadap perlindungan yang seyogiyanya didapatkan oleh anak dirasakan semakin rendah, baik perlindungan dari pihak keluarga, masyarakat, dan pemerintah.

Rendahnya perhatian dan perlindungan terhadap anak, berdampak suramnya terhadap nasib anak di masa depan, dan tidak menutup kemungkinan akan terjadi "Ioose generation". Hal ini, dapat kita lihat dari realitas kehidupan masyarakat yaitu adanya kecenderungan meningkatnya jumlah anak yang melakukan pelanggaran hukum. Sepanjang tahun 2000 tercatat dalam statistik kriminal kepolisian terdapat 11.334 anak yang disangka sebagai pelaku tindak pidana, pada bulan Januari hingga Mei 2002, diketemukan 4325 tahanan anak di Lapas seluruh Indonesia (Purnianti : 2002). 
Lebih menyedihkan, sebagian besar $(84,2 \%)$ anak-anak ini berada di dalam Lapas untuk orang-orang dewasa dan pemuda. Jumlah anak-anak yang ditahan tersebut tidak termasuk anak-anak yang ditahan dalam kantor polisi (Polsek, Polres, Polda, Mabes). Pada rentang waktu yang sama, yaitu Januari hingga Mei 2002, tercatat 9.465 anak-anak berstatus sebagai anak didik tersebar di seluruh Lapas (Purnianti, 2002).

Hasil pemantauan Balai Pemasyarakatan (Bapas; 2005) diperoleh gambaran tentang kondisi perkembangan anak didik Lapas, khususnya anak didik di Lapas Anak Tangerang, setelah kembali ke masyarakat tidak seluruhnya dapat beradaptasi dan diterima baik oleh keluarga maupun masyarakat dimana anak didik berada. Bahkan ada sejumlah anak didik Lapas (30 \%) mengulang kembali perbuatan melanggar hukum tersebut.

Ada beberapa faktor yang turut mempengaruhi sehingga anak kembali melakukan pelanggaran, berdasarkan hasil observasi peneliti di lapangan dan beberapa hasil penelitian yang telah dilakukan oleh tim peneliti Departemen Kriminologi UI tahun 2000, khususnya dilihat dari kualifikasi pendidik, perencanaan, pendekatan dan metodologi pendidikan, dan sistem evaluasi.

Berdasarkan data realitas tentang dinamika kehidupan anak didik di Lapas Anak Tangerang tersebut, dalam upaya meningkatkan kualitas 
pendidikan anak didik baik pada masa kini maupun dimasa yang akan datang. Betapa masih rendahnya perhatian keluarga, masyarakat dan pemerintah terhadap perlindungan dan pendidikan anak, hal ini mengusik nurani peneliti yang paling dalam untuk sedikit membantu memberikan solusi terbaik, yakni perlu adanya penerapan dan pengembangan model pendidikan konvergensi antara fungsionalis dan religious bagi anak didik di Lapas Anak Tangerang.

\section{B. Fokus dan Rumusan Masalah}

Berdasarkan fenomena yang terungkap pada latar belakang masalah tersebut diatas, terlihat bahwa permasalahan yang dihadapi dalam optimalisasi kualitas "Pendidikan bagi anak didik di Lapas Anak Tangerang" dewasa ini adalah : (1) terjadinya kontradiksi antara nilainilai harapan (das Sollen) dengan nilai-nilai realitas (das Sein), yaitu seharusnya bahwa pendidikan/pembinaan di Lapas Anak tersebut mampu mendidik anak menjadi sadar hukum, namun pada kenyataannya belum oftimal, (2) faktor dominan yang mempengaruhi kualitas "Pendidikan anak didik di Lapas Anak Tangerang" adalah komponen instrumental input pendidikan, yang meliputi kualifikasi pendidik, perencanaan, pendekatan dan metodologi pendidikan, dan sistem evaluasi. Paling tidak yang menjadi harapan bila seorang anak telah mengikuti pembinaan, baik 
didalam Lapas maupun diluar Lapas akan melahirkan (output) anak menjadi sadar hukum.

Berdasarkan identifikasi masalah tersebut, maka yang menjadi persoalan inti sekaligus fokus telaah dalam penelitian ini adalah, komponen pendidikan apakah yang paling menentukan kesadaran hukum

anak didik, mengapa setelah keluar Lapas tidak lebih baik dan bagaimanakah keterkaitannya dengan faktor internal dan eksternal yang mempengaruhi anak didik di Lapas Anak Tangerang ?.

Masalah pokok di atas, setelah dianalisis nampak akan menyangkut berbagai aspek secara meluas, maka untuk terarahnya studi ini dibatasi pada apsek instrumental input pendidikan di dalam Lapas anak Tangerang sehingga tidak mengulang lagi perbuatan melanggar hukum setelah anak keluar dari Lapas, dengan fokus masalah penelitian sebagai berikut :

1. Komponen instrumental input pendidikan apakah yang paling menentukan kesadaran hukum anak didik Lapas ?

2. Faktor-faktor internal apakah yang dapat mengembangkan kesadaran hukum anak didik Lapas ?

3. Faktor-faktor eksternal apakah yang dapat mengembangkan kesadaran hukum anak didik Lapas ? 


\section{METODE PENELITIAN}

\section{A.Spesifikasi dan Materi Penelitian}

Penelitian ini menggunakan penelitian naturalistik kualitatif. Sesuai dengan pendapat Lincoln dan Guba (1985 : 37); pertama, realitas yang ada pada dasarnya bersifat ganda, terkontruksi dan holistik; kedua, antara orang yang mengetahui (knower) dan apa yang diketahui (known) bersifat interaktif dan tak terpisahkan; ketiga, hanya waktu dan konteks yang memungkinkan berkaitan dengan kerja; keempat, semua entitas yang ada dalam kondisi saling simultan sehingga hampir-hampir tidak mungkin membedakan antara sebab dengan akibat; kelima, penelitian pada dasarnya tidak bebas nilai. Adapun secara lengkap desain langkah-langkah kegiatan penelitian di visualisasikan sebagai berikut :

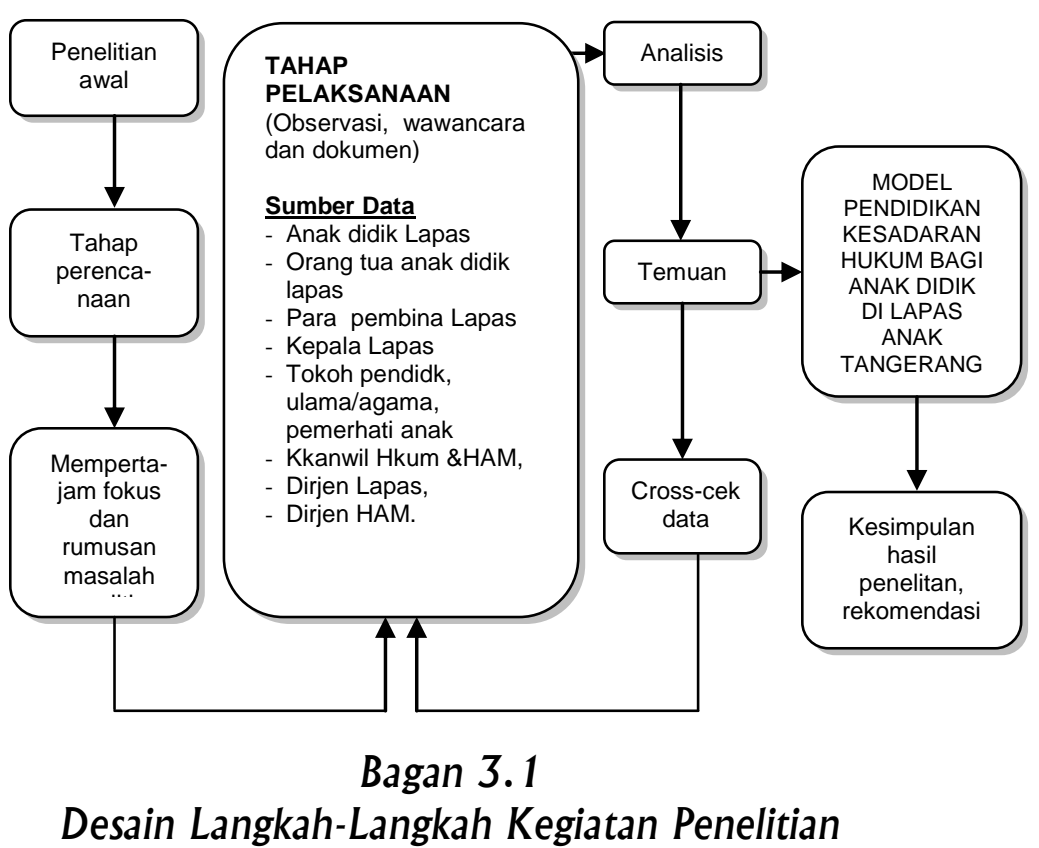


Penelitian kualitatif ini lebih bersifat natural, deskriptif, induktif, dan menemukan makna dari suatu fenomena (Bogdan dan Biklen, 1982 : 29 -31; Nasution, 2003: 12; Moleong, 1996 : 4 8). Adapun sifat natural diartikan bahwa penelitian kualitatif mempunyai latar yang alami sebagai sumber data langsung. Peneliti masuk secara langsung ke dalam latar pendidikan di Lapas Anak Tangerang. Pentingnya masuk dalam latar alamiah tersebut, karena peneliti sangat memperhatikan konteks. Berbagai fenomena pendidikan dapat dipahami dengan lebih baik jika diamati di latar tempat terjadinya. Bagi peneliti kualitatif (Bogdan dan Biklen, 1982 : 27), melepaskan tindakan, ucapan, atau gerak isyarat dari konteksnya berarti kehilangan makna penting.

Analisis data dalam penelitian ini bersifat induktif. Peneliti tidak mencari data untuk membuktikan atau menolak hipotesis yang dibuat sebelumnya melainkan membuat abstraksi ketika fakta-fakta khusus telah terkumpul dan dikelompokkan bersama-sama. Analisis induktif (Patton, 1987 : 306) berarti bentuk-bentuk, tema-tema, kategori-kategori suatu analisis berangkat dari data. Penganalisis mencari variasi dari data yang ada. 
Makna ditemukan dari fenomena pendidikan di Lapas Anak Tangerang setelah proses pengamatan, berinteraksi dengan orangorang, pemahaman bahasa dan tafsiran mereka tentang dunia sekitarnya, yang ada pada latar penelitian. Peneliti kualitatif (Brannen, 1997 : 11) menggunakan lensa-lensa yang lebar, mencari pola-pola antar hubungan antar konsep-konsep yang sebelumnya tidak ditentukan. Pada akhirnya, peneliti berupaya menemukan model pendidikan kesadaran hukum, dan faktor-faktor internal dan eksternal yang mempengaruhi proses pendidikan di Lapas Anak Tangerang pada latar penelitian.

B. Lokasi Penelitian

Di Lembaga Pemasyarakatan Anak Pria dan Wanita Tangerang dengan pertimbangan bahwa Lembaga Pemasyarakatan ini (1) menempatkan pendidikan kesadaran hukum dalam konteks pengembangan kepribadian utuh; (2) khususnya Lembaga Pemasyarakatan Anak Wanita memiliki penataan demografi yang konstruktif untuk melakukan pendidikan/pembinaan anak didik; (3) telah mengelaborasi pendidikan formal mulai dari tingkat SD, SLTP, dan SMU, sebagai bagian dari sistem pendidikan/pembinaan; (4) telah melakukan kerjasama baik dengan lembaga/instansi terkait di dalam negeri maupun dengan lembaga-lembaga donor dari luar negeri. 


\section{Teknik Pengelohaan dan Analisis Data}

Dalam teknik pengolahan dan analisis data dilakukan langkahlangkah yang sesuai dengan tradisi penelitian kualitatif, khususnya dalam penelitian ini dilaksanakan melalui langkah-langkah sebagai berikut :

1. Kategorisasi dan kodifikasi, pada tahap ini data yang telah terkumpul ditulis dalam bentuk kartu data, kemudian dikategorisasikan dengan pembubuhan kode, tentunya pengkodean ini disesuaikan dengan pedoman kode yang telah dipersiapkan sebelumnya. Kategori dan kodifikasi data ini diperlukan untuk memudahkan dalam interpretasi dan verfikasi data selanjutnya (A. Chaedar A. 2003 : 160).

2. Reduksi data, pada tahap ini data yang terkumpul dari lapangan setelah dikategorisasi kemudian dikodifikasikan dalam bentuk laporan yang rinci, kemudian direduksi, dirangkum, dipilih hal-hal yang pokok dan difokuskan pada hal-hal penting. Data yang tidak relevan dengan hal-hal penting menurut penelitian ini direduksi dan dieleminir untuk disisih dari proses pengolahan selanjutnya. Sebelum direduksi data tersebut terlebih dahulu dianalisis dan 
dicoba dibuat kategorisasi baru juga memungkinkan karena tidak ada relevansinya, maka data tersebut baru direduksi.

3. Display dan klasifikasi data, pada tahap ini untuk dapat melihat gambaran keseluruhan atau bagian-bagaian tertentu, maka akan dilakukan klasifikasi dengan menggunakan berbagai matriks. Kalasifikasi dilakukan dengan menggunakan kode yang digunakan pada tahap ketegorisasi.

4. Membuat kesimpulan dan verifikasi, sebenarnya pada penelitian ini mengambil kesimpulan dilakukan sejak awal, namun terus menerus dikembangkan dan diverifikasi selama penelitian berlangsung. Pada tahapan ini peneliti berupaya mencari data yang baru atau memperdalam dan mempertajam penelitian yaitu dengan melakukan "inter-subjective consensus". Adapun langkah-langkah ini

diperlukan pertanyaan penelitian sebagai langkah awal penelitian lapangan. Langkah tersebut pada dasarnya bukan suatu yang harus berurutan akan tetapi dapat berjalan bersama-sama secara terus menerus selama berlangsungnya penelitian sehingga dapat merumuskan berbagai gagasan konseptual dan operasional dalam pengembangan dan peningkatan kualitas pendidikan kesadaran hukum bagi anak didik Lembaga Pemasyarakatan Anak Tangerang. 
5. Melakukan analisis makro dimana peneliti secara langsung memperhatikan tingkatan yang bersifat kolektif, sistem, kelembagaan, gabungan, atau kelompok. Adapun dalam analisis mikro, peneliti memusatkan perhatiannya pada bagian-bagian subsistem-subsistem, yaitu individu-individu yang membentuk kolektivitas kriminalitas sosial.

\section{HASIL PENELITIAN DAN ANALISIS}

A. Hasil Penelitian

Adanya temuan hasil penelitian tentang proses pendidikan yang dilaksanakan di Lapas anak Tangerang, yang menentukan kesadaran hukum anak didik di Lapas Anak Tangerang, dan keterkaitannya dengan faktor - faktor internal dan eksternal, yang ditemukan pada penelitian ini adalah :

Pertama, kualifikasi pendidik/pembina, yang memiliki sifat-sifat kasih sayang, jujur, dijadikan suritauladan, memahami aspek psikologi anak didik dan mendekatkan diri pada Tuhan. Dapat mendorong proses pendidikan bagi anak didik di Lapas Anak Tangerang.

Kedua, Perencanaan pembinaan, dengan menggunakan perpaduan kedua model yaitu secara top down dan bottom up, dimaksudkan dapat menjembatani kesenjangan antara harapan 
program pembinaan dengan realitas di Lapas. Pihak pusat (Dirjen Lapas) telah memberikan keleluasaan untuk berimprovisasi dan berkreasi kepada Lapas untuk mengembangkan metode pembinaan yang relevan dengan kondisi Lapas. Secara bottom up perlu juga dikembangkan metode pembinaan yang sesuai dengan kondisi tiap-tiap Lapas.

Ketiga, pendekatan dan metode pembinaan yang mengkombinasikan antara model fungsionalis dan religious, akan menjadi sinergitas yang konstruktif sebagai suatu model pembinaan anak didik Lapas di masa depan. Melalui pendekatan dan metode pembinaan dengan :

a. Mengedepankan: (1) keteladanan, (2) pembiasaan dan latihan, (3) penciptaan situasi yang kondusif dengan: suasana, sistem , sarana dan prasarana, karya dan prestasi, seni dan budaya, dan (4) kedisiplinan, dapat mendorong akselerasi kesadaran hukum anak didik Lapas.

b. Pendekatan pembinaan melalui interaksi yang terjadi antar anak didik (pidana, negara, dan sipil), yang memiliki perbedaan jenis kejahatan dan riwayat kejahatan berdampak terhadap satu sama lainnya. 
c. Pendekatan secara individual dan kolektif, perlu diterapkan pada anak didik laki-laki maupun perempuan.

d. Semangat kebersamaan pada anak didik wanita lebih tinggi, dibandingkan dengan anak didik laki-laki.

e. Melalui internalisasi dan personalisasi kesadaran religious, dapat mengembangkan kesadaran diri, kejujuran, disiplin, kepercayaan diri, kepedulian dan kebersamaan.

f. Melalui kunjungan orang tua (keluarga) dengan penuh kelembutan, memberikan dorongan yang kuat dalam akselerasi proses pembinaan anak didik di dalam Lapas.

g. Pendidikan formal yaitu jenjang SD, SLTP, dan SLTA di dalam Lapas, yang setara dengan di luar Lapas, turut memberikan kontribusi yang signifikan dalam proses pembinaan anak didik Lapas.

h. Pendidikan keluarga inti (orang tua) dengan penuh perhatian, memegang peran strategis dalam membina anak didik Lapas pasca pembinaan di dalam Lapas

i. Meminimalisir/menghilangkan stigma keluarga dan masyarakat, terhadap anak didik Lapas sebagai anak jahat, mendorong anak didik Lapas untuk kembali kepangkuan keluarga dan masyarakat secara normal. 
Keempat, evaluasi pendidikan. Evaluasi Pendidikan di Lapas Anak Tangerang, belum berjalan optimal, perlu melibatkan peran anak didik, keluarga, dan masyarakat secara optimal, sehingga berfungsi sebagai feed back terhadap peningkatan kualitas pembinaan yang seharusnya dilaksanakan di Lapas.

\section{B. Analisis}

1. Analisis berdasarkan Temuan Penelitian

1.1 Peranan Pendidik/Pembina, Perencanaan, Metodologi dan Pendekatan, dan Evaluasi dalam Pendidikan Kesadaran Hukum bagi Anak Didik Lapas.

Temuan pertama adalah melalui kualifikasi pendidik/pembina yang memiliki kepribadian beriman dan bertaqwa, ramah, berwawasan luas, dan berempati, turut memberikan suasana yang kondusif dan memungkinkan anak didik Lapas memahami perbuatan yang menyebabkan mereka masuk ke Lapas, serta mampu memunculkan penyesalan atas perbuatannya dengan bimbingan dari para pendidik/pembina yang penuh kelembutan bukan dengan jalan kekerasa dan paling tidak memahami aspek psikologis anak sebagaimana pendapat Erik Erikson (http://childrengarden. wordpress.com, diunduh 5-6-2014), bahwa :

"pada usia 6-11 tahun pada diri anak terjadi dimensi polaritasnya memperoleh perasaan gairah dan di pihak lain 
mengatasi perasaan rendah diri. Dalam hubungan sosial yang lebih luas, anak menyadari kebutuhan untuk mendapat tempat dalam kelompok seumurnya".

Hal ini dibuktikan dari pendapat Andri Irawan (anak didik Lapas pria) bahwa merasa menyesal atas segala perbuatannya dan benar-benar merasa tersentuh setelah melihat dan mengikuti kelembutan bimbingan pendidik/pembina, layaknya kasih-sayang orang tua kepada anaknya, bahkan lebih jauh Andri Irawan menyatakan sangat membeci kepada pendidik/pembina yang melakukan pembinaan dengan jalan kekerasan. Putri (anak didik negara Lapas wanita) merasa lebih betah tinggal di Lapas dari pada di rumah sendiri, karena pendidik/pembina dengan penuh keramahan dan bertindak menjadi orang tua di Lapas. Putri juga merasakan sentuhan seorang pendidik/pembina yang mampu menggantikan peran seorang ibu, yang lebih tahu tentang dirinya merasa lebih diperhatikan, dan lebih jauhnya merasa terharu atas segala perbuatan yang menyeretnya masuk ke Lapas, sehingga melahirkan penyesalan yang mendalam dan bertekad untuk tidak mengulang perbuatannya, dan berupaya untuk hidup di masa depan yang lebih baik.

Berkait dengan sifat-sifat seorang pendidik/pembina, AIGhazali (Fathiyah Hasan, 1990 : 43) menyatakan bahwa 
"seyogiyanya seorang pendidik yang sempurna akalnya, terpuji budi pekertinya dan layak menjadi pengemban tugas pendidik secara umum " harus memiliki sifat-sifat khusus dalam mengemban tugasnya yaitu sebagai berikut : (1) harus memiliki sifat kasih sayang dan lemah lembut, (2) tidak bersifat komersial (selalu menuntut upah), (3) menjadi pembimbing yang jujur dan terpercaya bagi murid-muridnya, (4) menjaga citra anak didik, (5) memiliki keteladanan (keluhuran budi dan bersikap toleransi), (6) melayani anak didik sesuai dengan kemampuannya, (7) harus memahami dan menguasai psikologi anak, dan (8) harus berpegang teguh pada prinsip.

Berkait dengan sikap dan perilaku yang ditampilkan oleh para pembina Lapas, temuan kedua, adalah metode pembinaan yang strategis yaitu dengan: (1) keteladanan (contoh), (2) pembiasaan dan latihan, (3) penciptaan situasi yang kondusif dengan: suasana, sistem , sarana dan prasarana, karya dan prestasi, seni dan budaya, serta (4) kedisiplinan, dapat mendorong akselerasi kesadaran hukum anak didik Lapas. Bukti-bukti yang mendukung temuan tersebut adalah pengakuan Rusina (anak didik Lapas wanita), bahwa yang paling berkesan dan sangat menyentuh nurani yang paling dalam adalah contoh/teladan yang baik oleh 
para pembina Lapas wanita yaitu beliau rajin melaksanakan shalat, perkataannya sopan dan penuh kelembutan serta selalu sabar memberikan bimbingan pada kami, bahkan kami merasakan adanya pengganti orang tua kami yang selama ini jarang bertemu.

Hal senada juga diungkapkan oleh Putri (anak didik Lapas wanita), sebenarnya kami di rumah diabaikan oleh orang tua dan kurang tampak orang tua memberikan keteladan, pembiasaan melakukan kegiatan yang positif, dan kedisiplinan, setelah kami masuk ke Lapas ternyata kami mendapatkan pembina yang sangat memperhatikan kami, dan merasa betah hidup di dalam Lapas. Pengakuan senada juga diungkapkan oleh Muhammad Hasan (anak didik Lapas pria) bahwa dirinya terkesan dan bahkan lebih jauhnya, menyadarkan dirinya yang telah berperilaku melanggar hukum, tiada lain setelah dirinya melihat sikap keteladan, kedisiplinan dalam proses pembinaan yang selama ini diberikan oleh para pembina Lapas. Lebih jauh Arif Rachman (Kepala Sekolah SMU Lab. School Jakarta) menyatakan, bahwa proses pembinaan/pendidikan bagi peserta didik adalah tidak lepas dari peran serta para pendidik. Para pendidik dituntut untuk mampu meletakan tujuan hidup yang hakiki, menanamkan kesadaran, mengembangkan kreativitas, melakukan pembinaan dengan 
melalui, tahap memberi informasi, kegiatan pelibatan, kegiatan alternatif, dan rehabilitasi serta memberikan keterampilan bagi anak didik Lapas sebagai bekal ketika kembali kepada masyarakat. Hal senada juga, dilontarkan oleh Lies (Ketua Rencana Aksi HAM Jawa Barat), bahwa keteladan yang di tampilkan oleh para pembina Lapas adalah merupakan salah satu unsur penting dalam proses pembinaan bagi anak didik Lapas.

Berkenaan dengan metode pendidikan/pembinaan yang konstruktif untuk diterapkan di Lapas oleh para pendidik/pembina, temuan ketiga, bertambahnya keyakinan anak didik yang tinggi kepada Allah SWT dapat mengembangkan keimanan, kepercayaan diri, kemandirian, kesabaran, dan kesadaran masa depan. Di antara bukti empirik yang mendukung temuan tersebut adalah (1) semakin tambah yakinnya Saip (alumni Lembaga Pemasyarakatan Anak Pria) bahwa berperilaku melanggar perintah Allah SWT di dunia saja sudah mendapatkan balasan apalagi di akhirat kelak. Keyakinan tersebut telah menjadikan Saip selalu tenang dan tentram, dengan setiap saat selama berada dalam Lembaga Pemasyarakatan selalu ingat dan berdzikir kepada Allah SWT, dan bukti kongkritnya Saip diangkat menjadi Ketua DKM Lapas (selama masa tahanan); (2) Sidiq 
(alumni Lembaga Pemasyarakatan) tiada kunci keselamatan dan kebahagian di dunia dan di akhirat kelak, kecuali dekat dan selalu ingat kepada Allah SWT.

Hal ini dibuktikan Sidiq selama berada di dalam Lembaga Pemasyarakatan selalu rajin dan tekun mengikuti segala kegiatan serta setiap saat selalu melaksanakan sholat, (3) Yana (anak didik Lapas Wanita), keadaan orang tua sudah tidak lengkap, yaitu ibu meninggal dan tinggal bersama bapak, adapun kasus yang dilakukan adalah mengkonsumsi narkotik. Masa tahanan yang telah dijalani adalah enam bulan, selama dalam Lapas mendapat pendidikan yang berkesan terutama pendidikan agama yang menyentuh adalah ceramah dan contoh dari pendidik/pembina, serta pengaruh teman-teman.

Berdasarkan bukti empiris di atas, keyakinan kepada Allah, telah menjadikan terinternalisasinya nilai kesadaran hukum : keimanan (keyakinan kepada Allah SWT, keyakinan Allah Maha Melihat atas segala perbuatan yang kita lakukan), kepercayaan diri dan kemandirian (mengisi kegiatan selama berada di dalam dan luar Lapas, dengan kegiatan yang berguna), kesabaran (menjalani hukuman dengan ikhlas dan berserah diri kepada Allah SWT), dan kesadaran masa depan (tujuan hidup di dunia untuk 
beribadah, dan meraih masa depan yang lebih baik), pada diri anak didik.

Kesuksesan seorang pendidik/pembina dalam menanamkan kesadaran hukum bagi anak didik, menurut penuturan Abah Anom (Pembina dan Pengasuh pondok pesantren Suralaya, Tasikmalaya), hanya bisa dicapai kalau seorang pendidik/pembina mempunyai mempunyai keyakinan sepenuh hati; keyakinan bahwa pada prinsipnya proses pendidikan/pembinaan adalah merupakan salah satu rangkaian ibadah kepada Allah SWT. Tentunya seorang pendidik/pembina tersebut mengimplementasikan segala bentuk ibadah kepada Allah SWT, diwujudkan dengan memiliki sikap-sikap profesionalisme sebagai seorang pendidik, baik dilihat dari aspek pedagogik, kompetensi, kecakapan sosial (kecakapan komunikasi), kecakapan profesionalnya, dan kesadaran masa depan.

Dengan sikap keteladan yang ditampilkan oleh para pembina yaitu dengan menjalankan shalat wajib secara berjamaah, menambah keyakinan anak didik yang tinggi kepada Allah, maka, temuan kelima, bahwa dengan shalat dapat mengembangkan kesadaran diri, kejujuran, disiplin, kepercayaan diri, dan optimisme. Bukti-bukti yang mendukung temuan tersebut, 
diantaranya dengan shalat (ibadah mahdhah dalam Islam), menurut pengakuan Farid Ismail (anak didik Lapas laki-laki) setelah melaksanakan shalat baik shalat wajib maupun sunat secara sungguh-sungguh, ada perasaan selalu terus dilihat dan diawasi Allah, dan selalu merasa berdosa terhadap perbuatan yang melanggar norma agama dan norma hukum. Penerapan ibadah shalat yang dilakukan oleh anak didik Lapas adalah merupakan metode tazkiyatun nafsi didasarkan kepada realitas bahwa shalat mempunyai hikmah yang mempengaruhi pribadi seseorang untuk tidak bertindak keji (pembunuhan, perzinahan, minu-minum keras dan sejenisnya) dan munkar (yaitu segala macam tindakan yang bersifat destruktif dan anarkhis). Hal ini didasarkan pada firman Allah (s.w.t).

"Sesungguhnya shalat itu mencegah (perbuatan perbuatan) keji dan mungkar". (Q.S. Al-Kabut (29) : 45).

Dengan metode shalat ini, akhirnya seseorang akan malu dan takut untuk berbuat maksiat, khususnya berbuat keji dan anarki. la juga akan senantiasa ingat kepada Allah, yang pada gilirannya akan terselamatkan dari godaan syetan. Selain manfaat psikologis yang bersifat terapeutik, shalat juga mempunyai manfaat somatic atau psikomatif. Hal ini disebabkan karena secara mekanis 
gerakan shalat memiliki aspek olah raga dan akupuntur yang bersifat terapeutik. Mulai dari kegiatan pra-shalat, yaitu wudlu ataupun mandi, dan seluruh gerakan dalam kegiatan shalat.

Berkenaan dengan hikmah yang diperoleh melalui shalat, maka, temuan keenam bahwa dengan dzikrullah dapat mengembangkan kejujuran, kepercayaan diri, disiplin, dan berpikir positif. Bukti-bukti yang mendukung temuan tersebut, diantaranya dengan dzikrullah (mengingat, merenungkan, dan taat) kepada Allah semata, menurut penuturan Saip (alumni Lapas Anak Pria) ada perasaan-perasaan seperti ada yang melihat, sehingga tercurah hanya untuk Allah. la merasa malu jika melanggar ketentuan Allah. Santi (tahanan Lapas Wanita) juga menuturkan dari apa yang ia dengar dari teman-temannya yang sudah mengikuti tahanan di Lapas wanita (ada aktivitas dzikir dan terus memacu untuk selalu berdzikir), menurut pengalamanya sendiri bahwa dzikir mempunyai dampak yang sangat positif, dan lebih bisa mengendalikan diri setelah menjalani pendidikan dan pembinaan selama berada di Lapas. Lala (Alumni Inabah Putri kasus narkotik) menuturkan dengan mengikuti kegiatan dzikrullah hati merasa 
tenang, nikmat dan menggetarkan seluruh perasaan dengan selalu mengingat Allah, bahkan berkeinginan mengajak teman-teman yang terlibat dengan narkoba untuk secepatnya segera taubat dan selalu dzikir baik dzikir jahr (keras/nyaring) maupun dzikir khofi (hati). Keinginan lebih dekat dengan Allah, mendapat pengampunan dari pada-Nya adalah merupakan implikasi dari berdzikir dan berdoa sebagaimana diungkapkan oleh Rusiana (anak didik Lapas wanita), bahkan Rusiana selain selalu rajin melaksanakan shalat wajib, juga rajin melaksanakan shalat sunat lainnya, sehingga dirasakan semakin mempertebal kesadaran diri dan menyatakan betul-betul bertobat, tidak akan melakukan perbuatan melanggar hukum lainnya.

Metode dzikir memberi dampak begitu besar terhadap percepatan proses penyadaran anak didik Lapas, berkait dengan hal ini, temuan ketujuh yang cukup menunjang terhadap proses pendidikan kesadaran hukum, khususnya bagi umat Islam adalah melalui ibadah puasa, yang didalamnya terkandung nilai kejujuran, kepedulian, kedisiplinan, kebersamaan, dan berpikiran positif. Sebagai bukti kongkrit penuturan dari Ali Wardhana (alumni tahanan Lapas anak pria) bahwa ajaran puasa (shaum) dapat 
melatih diri kita untuk menahan diri dari (makan, minum, dan berhubungan seks) serta dari segala perbuatan maksiat. Sarah (anak didik Lapas wanita) menyatakan bahwa dengan melakukan ibadah shaum, baik shaum wajib maupun sunat, merasa terlatih secara psikologis untuk berperilaku disiplin dan meningkat kemampuan pengendalian diri. Sedangkan Muhamad Hasan (anak didik Lapas pria) merasakan bahwa dengan melakuan ibadah puasa (shaum) dapat memperhalus perasaan kesetiakawanan sosial, karena dengan latihan merasakan lapar dan dahaga yang pada gilirannya dapat menekan sikap ambisi yang membabi buta, rakus, dan egois.

Lebih jauh menurut Al-Amiri ( Aqib kharisudin, 2005 : 193) seorang filosof muslim, gerak dan pemikiran manusia itu dikendalikan oleh tiga tabiat, yaitu tabiat kebinatangan, tabiat kemanusian, dan tabiat kemalaikatan. Tabiat kebinatangan seperti makan dan seks kalau dituruti sesuai keinginannya, maka ia akan mengarahkan manusia kearah kehidupan yang lebih rendah (binatang). Sedangkan tabiat kemalaikatan seperti rindu dan asyik berdekatan dengan Tuhan, akan mengarahkan kehidupan manusia pada kehidupan alam atas( alam malaikat). Tabiat manusia berada diposisi tengah-tengah, sebagai upaya mempersempit ruang gerak 
tabiat kebinatangan, maka manusia akan meningkatlah tabiat kemalaikatannya, begitu juga sebaliknya. Ibadah puasa (shaum) bagi anak didik Lapas selain memberikan manfaat psikologis, puasa juga sangat berguna untuk kesehatan fisik, psikomatik seperti terciptanya kesehatan dan keseimbangan asam-basa lambung, karena stress, tekanan darah tinggi, terlalu banyak kolesterol dan lain-lain.

Selain temuan yang bersifat konstruktif juga ada temuan yang bersifat destruktif, temuan kedelapan, bahwa interaksi yang terjadi antar anak didik dengan anak didik lainnya yang memiliki perbedaan jenis kejahatan dan riwayat kejahatan akan berdampak terhadap satu sama lainnya.

Diantaranya antara anak sipil dengan anak pidana, hal ini sebagaimana pengakuan Putri (anak didik Lapas wanita), ia menuturkan setelah dia bergaul di Lapas dengan anak didik pidana dan anak negara ia menjadi banyak informasi tentang riwayat kejahatan yang pernah dilakukan oleh teman-temannya, tentunya hal ini akan mempengaruhi terhadap perkembangan kejiwaannya. Hal yang senada juga diungkapkan oleh Asep Setiarasa (anak didik sipil Lapas pria), bahwa selama ia berada dalam Lapas bergaul dengan rekan-rekan anak didik yang memiliki berbagai latar 
riwayat kejahatan yang pernah dilakukannya, sehingga menjadi tahu tentang segala riwayat kejahatan yang pernah dilakukan oleh teman-temannya tersebut, dan merasa dirinya merupakan bagian kelompok anak didik yang memiliki berbagai riwayat kejahatan yang pernah dilakukannya. Seyogiyannya proses pendidik/pembinaan bagi anak didik sipil, tidak disatukan dengan anak didik Lapas lainnya, tetapi khusus diarahkan untuk pembinaan anak-anak nakal.

Berkait dengan proses pendidikan didalam Lapas, ternyata perhatzan/kunjungan orang tua (keluarga) memberikan kontribusi yang sigifikan dalam proses pembinaan anak didik di Lapas, maka temuan kesembilan, Intensitas kunjungan orang tua (keluarga) terhadap anak didik Lapas, memberikan dorongan yang kuat dalam akselerasi proses pembinaan/pendidikan anak didik di dalam Lapas. Dengan adanya kunjungan orang tua (keluarga) ke Lapas, paling tidak bagi anak didik Lapas tersebut merupakan merupakan sesuatu yang sangat berharga, yaitu adanya pengakuan eksistensi dirinya dalam kehidupan keluarga, sehingga hal ini merupakan dorongan yang kuat bagi anak didik untuk tidak mengulang kembali perbuatan yang melanggar hukum. Bahkan bagi beberapa orang anak didik Lapas (pria dan wanita) adanya kerinduan yang 
mendalam untuk kembali ke lingkungan keluarga yang penuh kedamain.

Esensi komunikasi edukatif yang dilakukan orang tua dengan anak, apalagi bila dilakukan secara sadar dengan tujuan untuk mendidik, hal ini tentunya akan mengantarkan anak didik ke arah kedewasaannya. Bagaimanapun anak didik Lapas secara lahiriah maupun bathiniah membutuhkan perhatian, bimbingan, dan dorongan kearah konstruktif dari orang tuanya secara optimal. Sebagaimana dikatakan oleh kak Seto Mulyadi (Ketua Perlindungan Anak Indonesia) bahwa orang tua jangan malu-malu untuk menjenguk anaknya di Lapas, bagaimanapun orang tua memiliki peranan strategis dalam pembinaan anak, sejauhmana peran orang tua (keluarga) dapat berfungsi sebagai edukatif dan perlindungan bagi anak-anaknya. Adapun bentuk penyimpangan perilaku yang dilakukan oleh anak adalah sebenarnya lebih diakibatkan kondisi yang kurang kondusif.

Dengan diselenggarakannya pendidikan formal yaitu jenjang Sekolah Dasar (SD), Sekolah Lanjutan Tingkat Pertama (SLTP), dan Sekolah Menengah Umum (SMU) didalam Lapas, temuan kesepuluh, bahwa pendidikan formal yang diselenggarakan di Lapas turut memberikan kontribusi yang signifikan dalam 
proses pembinaan anak didik Lapas, hal ini dibuktikan dengan adanya beberapa anak didik yang mengikuti pendidikan formal tersebut, bahwa dirinya merasa terpacu untuk tidak mengulang kembali perbuatan melanggar hukum tersebut, bahkan lebih jauh ingin meraih prestasi dan tak ingin ketinggalan dengan temantemannya yang berada di luar Lapas.

Peranan sekolah formal cukup strategis untuk terus dikembangkan, sebagaimana dikatakan oleh Sopyan Syauri (2006: 45), bahwa peranan sekolah tidak berhenti pada pewarisan dan pelestarian nilai, tetapi menjadi lokomotif pembaharuan masyarakat. Namun kendala yang dihadapi adalah sarana dan prasarana yang tersedia, serta terbatasnya waktu, yaitu bahwa mereka mengikuti pendidikan formal di Lapas adalah sesuai dengan lamanya anak didik menjalani hukuman di dalam Lapas.

Berkait dengan diselenggarakannya pendidikan formal didalam Lapas, ternyata pendidikan keluarga inti (orang tua) memegang peranan yang sangat esensial dalam mendidik dan membina anak-anak. Temuan kesebelas, adalah bahwa orang tua (keluarga inti) seyogiyanya dalam mendidik dan membina anak, mampu mengembangkan kematangan kehidupan sosial psikologis 
anak-anaknya. Adapun citra positif sebagai orang tua adalah teladan bagi anak-anak untuk siap memasuki kehidupan sosialnya. Keluarga juga memiliki peranan yang strategis dalam mengembangkan pendidikan kesadaran hukum bagi anak-anak. Pendidikan kesadaran hukum yang paling awal diterima dan diserap oleh anak adalah melalui lingkungan keluarga, dengan melalui keluarga (orang tua) inilah anak-anak pertama kali mendapatkan pendidikan kedisiplinan, ketaatan, tolong menolong, kepedulian, kejujuran, dan ketaqwaan kepada Tuhan Yang Maha Esa.

Peranan keluarga (orang tua) selain berperan sebagai pelindung anggota, pencukup kebutuhan ekonomi, penyelenggara rekreasi, dan pendidik dalam kehidupan keluarga. Sopyan Syauri (2006 : 83) menyatakan bahwa kepala keluarga yang beriman yang patut menjadi panutan bagi anggota keluarganya bukanlah yang selalu berbuat baik sendiri, melainkan selalu mencontohkan bagi semua anggota keluarganya untuk selalu berbuat baik.

Pendidikan kesadaran hukum sebagai salah satu dimensi pendidikan kehidupan keluarga, tidak terlepas dari dua pemegang peran utama dalam interaksi edukatif dalam keluarga yaitu orang tua dan anak. Dalam interaksinya kedua belah pihak mempunyai 
peranan masing-masing, yaitu orang tua berperan sebagai pendidik dengan mengasuh, membimbing, memberi teladan, dan membelajarkan anak. Sedangkan eksistensi anak sebagai peserta didik, melakukan kegiatan belajar dengan cara berpikir, menghayati, dan berbuat di dalam dan terhadap dunia kehidupannya.

Apa yang harus dimiliki orang tua sebagai pendidik agar mampu mempersiapkan kehidupan sosial anak-anak untuk selalu siap dan sigap berinteraksi secara positif dengan fenomenafenomena sosial dewasa ini. Orang tua sebagai pendidik harus mampu mempengaruhi anak-anak dengan warna dasar kesadaran diri (kesadaran hukum) dan kesadaran kolektif. Lebih jauh Ari Ginanjar A (2004: 218) menyatakan bahwa untuk melahirkan kesadaran diri yang hakiki, maka seseorang harus mampu mengintegrasikan kecerdasan emosional (EQ), kecerdasan intelektual (IQ), dan kecerdasan spiritual (SQ), sehingga dapat melahirkan meta kecerdasan.

Kesadaran diri merupakan suatu kecakapan yang dapat dijabarkan menjadi; (1) kesadaran diri sebagai hamba Tuhan, makhluk sosial, serta makhluk lingkungan, dan (2) kesadaran akan potensi yang dikaruniakan oleh Tuhan, baik fisik maupun 
psikologik (http:/www.dikmenum. go.id). Kesadaran diri sebagai hamba Tuhan diharapkan mendorong yang bersangkutan untuk beribadah sesuai dengan tuntunan agama yang dianut, berlaku jujur, bekerja keras, disiplin dan amanah terhadap kepercayaan yang dipegangnya, tentunya hal ini salah satunya dapat diimplementasikan dalam pelajaran agama (misal pengajian rutin: bagi anak didik yang beragama Islam), dan juga dapat diimplementasikan dalam materi pembinaan lainnya.

Pendidikan kesadaran hukum bagi anak didik Lembaga Pemasyarakatan Anak, tidak bisa terlepas dari peranan masyarakat dimana anak didik itu tinggal. Maka temuan keduabelas bahwa Tajamnya pencitraan masyarakat terhadap anak didik Lapas sebagai anak jahat, menyulitkan anak didik Lapas untuk kembali kepangkuan kehidupan keluarga dan masyarakat secara normal. Bagaimanapun proses pembinaan kesadaran hukum bagi anak didik Lapas, merupakan bagian yang tidak terpisahkan dengan kehidupan masyarakatnya. Tentunya kondisi kehidupan masyarakat yang kondusif, yaitu dengan adanya sikap penerimaan yang baik dari anggota masyarakat adalah merupakan faktor eksternal yang turut memberikan kontribusi yang signifikan 
terhadap kesinambungan proses pembinaan bagi masa depan kehidupan anak didik Lapas yang lebih baik.

Padahal menurut Kakanwil Hukum dan Ham propinsi Banten, bahwa sudah saatnya masyarakat mengubah paradigma, terhadap anak didik Lapas. Tidak memandang lagi anak didik Lapas sebagai sampah masyarakat. Lebih jauh Romli Atmasasmita (1982 : 55), bahwa "labeling-process" atau "stigma" yang tengah berkembang di masyarakat Indonesia dewasa ini akan menghambat proses resosialisasi nara-pidana. Padahal pengaruh kehidupan masyarakat dikaitkan dengan perbuatan kriminalitas yang dilakukan oleh anak didik Lapas, manurut Abdulsyani (1987 : 70) ada beberapa gejala pokok sosiologis di dalam proses sosial yang berkait dengan kriminalitas (kejahatan), yaitu :

1. mobilitas sosial; Jika ditinjau dari sudut kepentingan, baik gerak sosial yang horizontal maupun gerak sosial yang vertikal, keduanya dimaksudkan untuk mengubah keadaan hidupnya kearah yang lebih baik dan lebih menyenangkan. Dalam hubungannya dengan timbulnya kriminalitas, gerak sosial vertikallah yang paling berpengaruh, sebab biasanya orang mempunyai kecenderungan berusaha untuk naik status daripada berusaha untuk pindah pekerjaan yang sederajat.

Timbulnya suatu kejahatan memang tidak harus secara langsung sebagai akibat dari adanya mobilitas, tetapi bisa merupakan antesenden dari terjadinya kejahatan itu. Kemudian dapat diduga bahwa perbandingan tingkat kejahatan antara daerah yang satu dengan daerah yang 
lainnya bergantung pada kebiasaan tingkah laku dan tingkat mobilitas penduduk daerah itu sendiri.

2. perbedaan organisasi sosial;

Perilaku menyimpang yang dilakukan oleh anak didik Lapas, tidak terlepas dari karakterisik organisasi sosial yang berkembang pada masa kini telah dipengaruhi oleh berbagai tujuan dan kepentingan khusus, dimana setiap anggotanya sudah semakin banyak menerima pengaruh aturan yang berubah-ubah sehingga tingkah laku anggota masyarakatpun memiliki banyak pola. Semakin banyak pola tingkah laku, banyaknya norma-norma baru yang berlaku, dan tidak menutup kemungkinan menimbulkan pertentangan-pertentangan sehingga ukuran bertingkah laku anggota kelompok menjadi terguncang dan tidak tegas.

Keadaan masyarakat dengan kondisi perkembangan organisasi sosial sebagaimana digambarkan tersebut, Astrid Susanto (1977 : 123) dikenal dengan "dis-organisasi". Yaitu masyarakat semakin tidak mempunyai persesuaian cita-cita atau tujuan-tujuan sebagaimana cita-cita sosial. Individu semakin banyak berhadapan dengan berbagai tujuan dan cita-cita pula, banyak norma dan nilai yang kurang dikenal, dan tidak menutup kemungkinan orang yang satu menganggap salah terhadap orang lain. Hal ini menunjukan bahwa pengaruh setiap orang atau kelompok relatif sudah banyak memberikan kesan ketidakstabilan, penyimpangan-penyimpangan, dan berbagai jenis tindak kejahatan. Keadaan yang rumit ini dapat menimbulkan kesulitan 
untuk menduga kepribadian seseorang di dalam suatu organisasi, apakah ia tergolong penentang atau tergolong pendukung dari suatu kejahatan.

Berkait dengan proses pembinaan anak didik Lapas pasca pembinaan di Lapas setelah kembali ke tengah-tengah keluarga/masyarakat perlu adanya pemantauan secara berkesinambungan, sebagai bahan masukan bagi Lapas dalam mengembangkan sistem pembinaan yang sedang dan telah dilaksanakan, maka temuan ketigabelas, evaluasi pendidikan. Evaluasi pendidikan di Lapas belum berkembang secara optimal, padahal evaluasi pendidikan merupakan faktor esensial sebagai feed back, terhadap kualitas pendidikan/pembinaan yang seharusnya dilaksanakan di lingkungan Lapas Anak.

Paling tidak Lapas dengan bantuan berbagai pihak mampu melakukan evaluasi secara portofolio, yaitu sistem penilaian/evaluasi yang lebih memfokuskan pada penilain proses dan hasil pendidikan (Sumarna Surapranata, S. dan Hatta, M, 2004 : 196). Seyogiyanya Lembaga Pemasyarakatan harus mampu melakukan monitoring atau mengevaluasi out putsnya secara secara integral. Khususnya monitoring atau evaluasi terhadap perilaku kehidupan anak didik ketika berada di tengah- 
tengah masyarakat dalam jangka waktu tertentu. Bahkan yang dievaluasi bukan hanya kepribadian anak didik saja tetapi seluruh faktor, baik faktor internal maupun faktor eksternal yang turut mempengaruhi terhadap seluruh perilaku narapidana dan anak didik baik sewaktu berada di dalam Lembaga Pemasyarakatan maupun setelah kembali ke masyarakat.

2. Analisis SWOT Pendidikan bagi Anak Didik Lembaga Pemasyarakatan Anak Tangerang.

a. Analisis SWOT di Lapas Anak Pria Tangerang

Proses pendidikan yang dilaksanakan di Lapas Anak Pria Tangerang baik dilihat dari komponen-komponen pendidikan yang meliputi : Pendidik/pembina dan peserta didik, perencanaan pendidikan, pendekatan dan metodologi pendidikan, dan sistem evaluasi memiliki beberapa keunggulan dan kelemahan, secara lebih rincinya adalah sebagai berikut :

1) Strength (Kekuatan)

a) penerapan sistem pendidikan formal sesuai dengan struktur dan tingkatan pendidikan meliputi : SD, SMP, SMU paket C, Pramuka, Paket B (PLS);

b) pendidikan dan bimbingan sudah mulai dilandasi dengan vocation rehabilitation dan education rehabilitation dengan 
mengetengahkan pola pembelajaran paket $B$ dan paket $C$, dari data 282 Anak Didik, 31, 8\% telah lulus paket B dan 64\% telah lulus paket C, sedangkan 3,6\% dinyatakan tidak Iulus.

2) Weakness (Kelemahan)

a) belum adanya pola pembinaan yang disesuaikan dengan penggolongan anak didik berdasarkan masa pidana, jenis kejahatan dan tingkat pendidikan ;

b) belum nampak pembinaan yang mengarah pada aplikasi pendekatan konvergensi antara fungsionalis dan humanistik. Tampak belum adanya pembinaan khusus didasarkan pada kesadaran tauhid, kesadaran diri, kepribadian, faktor internal dan faktor eksternal yang mempengaruhi perkembangan Anak Didik, walaupun memang sudah ada pengelompokan berdasarkan kelompok : AI, AII, AIII, BI, BII, BIIA, BIIB, BIII;

c) belum optimalnya pemanfaatan metode pembinaan dengan menggunakan nilai-nilai religi (Islam) secara mendalam, sebagaimana telah dilakukan metode terapi (penyembuhan) oleh beberapa pesantren; 
d) pembinaan yang dilakukan kurang dari satu tahun, bagi Anak Didik dengan menggunakan Half Way System, hal ini disebabkan kurangnya waktu dalam melakukan pembinaan;

e) belum terbangunnya sistem evaluasi yang berkesinambungan, yaitu dengan menggunakan sistem portofolio, sehingga bimbingan lanjutan tidak berjalan sebagaimana diharapkan, hal ini kurangnya perhatian dari pemerintah, masyarakat, dan pihak keluarga;

f) masih kurangnya sumber daya pendidik/pembina yang memenuhi kualifikasi sesuai dengan target yang diharapkan, yang akhirnya hanya bersifat formalistik saja;

g) metodologi dan materi pendidikan yang diberikan kepada Anak Didik belum menyentuh target dan tujuan akhir pendidikan bagi Warga Binaan, hal ini dilatarbelakangi oleh rendahnya kemampuan membaca para pendidik/pembina terhadap seluruh potensi, latar belakang riwayat kejahatan Anak Didik dan masih dangkalnya materi pendidikan yang dinuansai nilai-nilai kebermaknaan (materi yang mengandung nilai filosofis, psikologis, dan agamis); 
h) masih minimnya peran bimbingan dan konseling terhadap seluruh anak didik, sehingga perkembangan perilaku dan sikap anak didik tidak secara mendalam belum tersentuh;

\section{3) Opportunity (Peluang)}

a) model pendidikan dengan menggabungkan pendekatan fungsionalis dan religious secara terpadu, yang dilandasi dengan pendidikan nilai dengan penuh kebermaknaan, perlu dikembangkan dengan basis filosofi PP No. 31 Tahun 1999 patut mendapat perhatian dan respon Departemen Hukum dan HAM untuk lebih ditingkatkan dan disempurnakan sehingga melahirkan pola-pola pembinaan Anak Didik yang tepat guna;

b) pola kerjasama yang telah dijalin dengan pihak III : selain dengan pihak Pengadilan, Kejaksanaan, POLRI, Departemen Kesehatan, Departemen Peridustrian dan Perdagangan, Departemen Pendidikan, Departemen Agama dan Pemerintah Daerah, Instansi Swasta, LSM, dan Lembaga-Lembaga terkait lainnya, perlu lebih ditingkatkan kemasa depan dengan memadukan model pembinaan dengan pesantren ;

c) pola pendidikan vokasional ( pengelasan, pertukangan, sablon, pangkas rambut, otomotif, dan elektro ), memberikan 
peluang untuk lebih dikembangkan dalam pemberdayaan Anak Didik dan juga bisa dikembangkan dalam pemberdayaan operasional Lapas itu sendiri;

d) meningkatkan anggaran pendidikan baik melalui APBN ataupun melalui lembaga-lembaga donor baik di dalam negeri maupun dari luar negeri yang sifatnya tidak mengikat, yang difokuskan untuk meningkatkan kualitas pelayanan kepada Anak Didik.

4) Threat (Ancaman)

a) kondisi kehidupan keluarga dan masyarakat yang belum kondusif terhadap penerimaan "eks napi" yang telah selesai menjalani hukuman, hal ini tentunya merupakan kendala bagi pendidikan/pembinaan Anak Didik untuk secepatnya menyesuaikan diri dalam menjalani hidupnya yang lebih baik dimasa yang akan datang;

b) pengaruh negatif dari perkembangan informasi dan teknologi mempengaruhi tatanan kehidupan keluarga dan masyarakat, sehingga berdampak baik secara langsung maupun tidak langsung terhadap perkembangan "mentalitas dan kepribadian Anak Didik"; 
c) perkembangan kehidupan ating-ekonomi, dan kehidupan beragama yang kurang kondusif di negara kita, turut mempengaruhi perkembangan kehidupan "mentalitas dan kepribadian Anak Didik" pada masa sekarang maupun di masa yang akan ating.

b. Analisis SWOT Pendidikan Lapas Anak Wanita Tangerang

1) Strength (Kekuatan)

a) sedikitnya jumlah Anak Didik Wanita memudahkan proses pendidikan, pembimbingan, dan pengawasan, sehingga dapat meningkatkan kualitas pelayanan terhadap setiap individu "Anak Didik" ;

b) usia kronologis Anak Didik Pemasyarakatan di Lapas Anak Wanita Tangerang memiliki rentang antara 16 sampai 21 tahun, paling tidak hal ini akan berdampak pada :

(1) memudahkan para pendidik/pembina dalam melakukan pembinaan termasuk dalam melakukan pembimbingan, dan pengawasan;

(2) memudahkan pemilahan dan pembagian kelompok "Anak Didik" sesuai dengan latar belakang, karakteristik, riwayat kejahatan, kepribadian, dan mentalitas, sehingga 
memudahkan pemberian materi, metodologi dan evaluasi pendidikan yang tepat bagi semua "Anak Didik";

(3) penempatan Anak Didik rata-rata satu kamar maksimum antara lima sampai sepuluh orang perkamar. Hal ini tentunya mempermudah dalam pengawasan dan hubungan interpersonal antar Anak Didik ;

(4) pendidikan, pembinaan, bimbingan, dan pengawasan telah mengarah pada pendidikan yang didasarkan pada vocational, educational, dan medical rehabilitation;

(5) jenis pendidikan vokasional yang diberikan sangat beragam (kursus kecantikan, komputer , memasak, payet, salon, main musik, budidaya anggrek, menjahit, dan menyulam), hal ini memberikan peluang yang lebih luas bagi "Anak Didik" untuk memilih jenis pendidikan vokasional yang sesuai dengan minat dan bakatnya;

(6) kerjasama yang dijalin dengan lembaga-lembaga pemerintah maupun no-pemerintah bersifat mutualisma (saling menguntungkan) dalam peningkatan kualitas pelayanan kepada "Anak Didik" yang pada gilirannya akan mempercepat dan mempermudah proses pendidikan yang telah diprogramkan. 
2) Weakness (Kelemahan)

a. tidak adanya pendidikan yang lebih menekankan pada "social rehabilitation" yang seyogiyanya diberikan pada pendidikan tahap akhir. Hal ini dapat kita lihat minimnya penggunaan masa cuti menjelang bebas maupun cuti menengok keluarga, yang sebenarnya hal ini merupakan hak Anak Didik dalam proses asimilasi;

b. Lembaga Pemasyarakatan Anak Wanita Tangerang menerima titipan Anak Tahanan Kepolisian, Kejaksaaan dan Pengadilan, dan Tahanan Wanita Dewasa, hal ini tentunya berdampak pada Anak Tahanan itu sendiri karena mereka tidak memperoleh fasilitas pembinaan, di satu pihak anggaran operasional Lembaga Pemasyarakatan Anak akan mengurangi anggaran kesejahteraan Anak Didik;

c. tidak menyertakan social report, dalam melakukan proses pendidikan dengan menggunakan pola "perpaduan fungsionalis dan humanistik", padahal social report adalah merupakan salah satu kelengkapan berkas proses pendidikan yang tepat diberikan untuk "Anak Didik";

d. rendahnya kualitas sumber daya pendidik/pembina Anak Didik Pemasyarakatan, padahal tugas pendidikan/pembinaan 
yang sungguh berat, yaitu mendidik/membina Anak Didik menjadi manusia seutuhnya, menyadari kesalahan, memperbaiki diri dan tidak mengulangi tindak pidana, sehingga nantinya dapat diterima kembali oleh lingkungan keluarga dan masyarakat, dan dapat berperan aktif dalam pembangunan serta dapat hidup secara wajar sebagai warga yang baik dan bertanggungjawab.

e. rendahnya dana operasional, hal ini berdampak pada rendahnya kualitas pembinaan dan pendidikan baik pendidikan formal maupun pendidikan non formal, serta lebih jauhnya terhadap kesejahteraan Anak Didik;

f. rendahnya sikap pro-aktif dari seluruh pembina/pendidik dalam mengimplementasikan pola pembinaan yang bersifat vocation dan educational rehabilitation, dan pola pendidikan yang masih bersifat "teacher oriented" belum menerapkan pendidikan yang bersifat "student oriented";

g. pemberian remisi yang masih didasarkan pada sifat formalitas pengurangan pidana dan tidak ditekankan pada perubahan perilaku positif, hal ini tentunya belum memberikan motivasi yang tinggi bagi Anak Didik untuk melakukan perubahan perilaku kearah yang lebih baik, dan tidak menutup 
kemungkinan bila hal ini tidak secepatnya ditangani "Anak Didik" akan menjadi korban kebijakan yang yang kurang tepat.

\section{3) Opportunity (Peluang)}

a) tingginya kunjungan pihak keluarga degan penuh kasih saying terhadap Anak Didik mendorong percepatan keberhasilan pendidikan, baik pembinaan kepribadian, mentalitas, dan kemandirian sebagai bekal anak didik dalam menjalani kehidupan di masa depan;

b) penataan demografi, letak dan bentuk bangunan di Lapas Anak Wanita Tangerang yang meliputi bangunan Rumah Induk dan beberapa paviliun sebagai peninggalan Sistem Pembinaan di zaman Belanda. Pembinaan dengan pola penempatan pada paviliun-paviliun yang dilakukan berdasarkan konvergensi fungsionalis dan sufistik model serta pengelompokkan berdasarkan usia, latar belakang kehidupan, jenis kejahatan yang dilakukan, sebenarnya dapat dijadikan acuan dan landasan sistem pembinaan yang inovatif.

4) Threat (Ancaman) 
a) belum optimalnya peran psikolog, dalam memberikan bimbingan dan konseling, untuk membantu proses pendidikan dan pembinaan dan sebagai masukan bagi pendidik/pembinan dalam melakukan pendekatan yang paling tepat bagi Anak Didik ;

b) pihak Pengadilan belum menyertakan social report yang telah dibuat oleh BAPAS (Balai Pemasyarakatan), padahal social report memiliki kedudukan yang sangat penting pola pembinaan yang tepat diberikan bagi Anak Didik;

c) adanya anggapan yang diberikan terutama oleh masyarakat terhadap Anak Didik setelah selesai mengikuti proses penahanan, sebagian besar $(60 \%$ menurut Tim Peniliti dari Fak. Hukum Unair, Tahun 2005) Anak Didik Pemasyarakatan merasa takut untuk kembali ke masyarakat ;

d) Lapas Anak Wanita Tangerang menerima titipan narapidana Wanita Dewasa dengan alasan penuhnya daya tampung Lapas narapidana Wanita Dewasa, tentunya hal ini secara psikologis akan memberikan dampak yang kurang baik pembinaan psikis Anak Didik Pemasyarakatan Tangerang;

e) belum terjalinnya pendidikan/pembinaan tindak lanjut setelah Anak Didik keluar dari Lembaga Pemasyarakatan, baik dengan 
pihak keluarga, masyarakat, dan lembaga-lembaga terkait baik secara langsung maupun tidak langsung yang turut terkait dalam pembinaan/pendidikan di masa yang akan datang.

\section{SIMPULAN DAN SARAN}

A. Kesimpulan

1. Komponen instrumental input pendidikan yang paling menentukan kesadaran hukum anak didik Lapas, adalah Pertama, kualifikasi pendidik/pembina, yang memiliki sifat-sifat kasih sayang, jujur, dijadikan suritauladan, memahami aspek psikologi anak didik, dan mendekatkan diri pada Tuhan. Dapat mendorong proses pendidikan bagi anak didik di Lapas Anak Tangerang. Kedua, perencanaan pembinaan, dengan menggunakan perpaduan kedua model yaitu secara top down dan bottom up. Secara bottom up perlu juga dikembangkan metode pembinaan yang sesuai dengan kondisi tiap-tiap Lapas. Ketiga, pendekatan dan metode pembinaan yang mengkombinasikan antara model fungsionalis dan religious, akan menjadi sinergitas yang konstruktif sebagai suatu model pembinaan anak didik Lapas di masa depan. 
2. Faktor-faktor internal yang dapat mengembangkan kesadaran hukum anak didik melalui pendekatan dan metode pembinaan dengan :

a. Mengedepankan: (1) keteladanan (contoh), (2) pembiasaan dan latihan, (3) penciptaan situasi yang kondusif dengan: suasana, sistem , sarana dan prasarana, karya dan prestasi, seni dan budaya, dan (4) kedisiplinan, dapat mendorong akselerasi kesadaran hukum anak didik Lapas.

b. Pendekatan pembinaan melalui interaksi yang terjadi antar anak didik (pidana, negara, dan sipil), yang memiliki perbedaan jenis kejahatan dan riwayat kejahatan berdampak terhadap satu sama lainnya.

c. Pendekatan pembinaan secara kolektif, lebih efektif diterapkan kepada anak didik wanita dibanding dengan anak didik laki-laki. d. Pendidikan formal yaitu jenjang SD, SLTP, dan SLTA di dalam Lapas, yang setara dengan di luar Lapas, turut memberikan kontribusi yang signifikan dalam proses pembinaan anak didik Lapas.

e. Pendidikan keluarga inti (orang tua) dengan penuh perhatian, memegang peran strategis dalam membina anak didik Lapas pasca pembinaan di dalam Lapas 
3. Faktor-faktor eksternal yang dapat mengembangkan kesadaran hukum anak Didik

a. Melalui kunjungan orang tua (keluarga) dengan penuh kelembutan, memberikan dorongan yang kuat dalam akselerasi proses pembinaan anak didik di dalam Lapas.

b. Melalui internalisasi dan personalisasi kesadaran religious, dapat mengembangkan kesadaran diri, kejujuran, disiplin, kepercayaan diri, kepedulian dan kebersamaan.

b. Meminimalisir/menghilangkan stigma keluarga dan masyarakat, terhadap anak didik Lapas sebagai anak jahat, mendorong anak didik Lapas untuk kembali kepangkuan keluarga dan masyarakat secara normal.

c. Evaluasi pendidikan di Lapas, belum berjalan optimal, perlu melibatkan peran anak didik, keluarga, dan masyarakat, sehingga berfungsi sebagai feed back terhadap peningkatan kualitas pembinaan yang seharusnya dilaksanakan di Lapas.

B. Saran

Kesimpulan hasil penelitian yang telah disajikan di atas, mendorong peneliti untuk mengemukakan beberapa saran sebagai berikut : 
1. Lebih mengoptimalkan kembali peran komponen instrumental input pendidikan yang paling menentukan kesadaran hukum anak didik Lapas, adalah Pertama, dengan meningkatkatkan kualifikasi pendidik/pembina. Kedua, mendesain kembali secara akurat perencanaan pembinaan, dengan menggunakan perpaduan kedua model yaitu secara top down dan bottom up yang lebih optimal. Secara bottom up perlu juga dikembangkan metode pembinaan yang

sesuai dengan kondisi tiap-tiap Lapas. Ketiga, mengoptimalkan kembali pendekatan dan metode pembinaan yang mengkombinasikan antara model fungsionalis dan religious, akan menjadi sinergitas yang konstruktif sebagai suatu model pembinaan anak didik Lapas yang efektif dengan membangun kesadaran anak untuk tidak mengulang perbuatannya.

2. Mengoptimalkan kembali peran Faktor-faktor internal yang dapat mengembangkan kesadaran hukum anak didik melalui pendekatan dan metode pembinaan dengan : Mengedepankan: keteladanan, pembiasaan, latihan dan kedisiplinan. Menerapkan Pendekatan pembinaan melalui interaksi yang terjadi antar anak didik (pidana, negara, dan sipil). Pendidikan formal yaitu jenjang SD, SLTP, dan SLTA di dalam Lapas serta pendidikan keluarga inti (orang tua) 
dengan penuh perhatian, memegang peran strategis dalam membina anak didik Lapas pasca pembinaan di dalam Lapas

3. Menguatkan Faktor-faktor eksternal yang dapat mengembangkan kesadaran hukum anak Didik, melalui kunjungan orang tua (keluarga) dengan penuh kelembutan, memberikan dorongan yang kuat dalam akselerasi proses pembinaan anak didik di dalam Lapas, melalui internalisasi dan personalisasi kesadaran religious, dapat mengembangkan kesadaran diri, kejujuran, disiplin, kepercayaan diri, kepedulian dan kebersamaan dan meminimalisir/menghilangkan stigma keluarga dan masyarakat, terhadap anak didik Lapas sebagai anak jahat, mendorong anak didik Lapas untuk kembali kepangkuan keluarga dan masyarakat secara normal.

Evaluasi pendidikan. Evaluasi pendidikan di Lapas, belum berjalan optimal, perlu melibatkan peran anak didik, keluarga, dan masyarakat, sehingga berfungsi sebagai feed back terhadap peningkatan kualitas pembinaan yang seharusnya dilaksanakan di Lapas.

\section{DAFTAR PUSTAKA}

Abdulsyani. 1987. Sosiologi Kriminalitas. Bandung : CV Remadja Karya. Aqib, K .2005. Inabah, Jalan Kembali dari Narkoba, Stress, dan Kesunyian Hati. Surabaya : Pt. Bina IImu. 
Atmasasmita, Romli. 1983. Kepenjaraan (Dalam Suatu Bunga Rampai). Bandung : CV Armico.

Brannen, J. 2005. Memadu Metode Penelitian (Kualitatif \& Kuantitatif)Terjemahan.Yogyakarta : Pustaka Pelajar.

Chaedar Alwasilah, A. 2003. Pokoknya kualitatif (Dasar-Dasar Merancang dan Melakukan Penelitian Kualitatif. Jakarta : PT Pustaka Dunia Jaya

Creswell, John W. 1997. Qualitative Inquiry And Research Design Choosing among Five Traditions. California: sage Publication.

Departemen Agama RI. 2000. Al-Quran dan Terjemahnya. Bandung : CV Penerbit Diponegoro.

Erik Erikson. 1963. Childhood and Society. (http://childrengarden. wordpress.com, diunduh 5-6-2014).

Ginanjar, Ary A.2005. Emotional Spritual Quotiont. Jakarta: PT Arga.

Hasan Sulaeman, F. 1990. Konsep Pendidikan Al-Ghazali. Jakarta : PT Guna Aksara.

Henry, Nelson.B. 1952. The -First Yearbook of The NationalSociety of Education, Part 1: General Education Chicago .Illinois :The University of Chicahgo Press.

H. Mc Millan and Schumacher, S. 2001. Research in Education (a Conceptual Introduction). New York : Addison Wesley Long man, Inc. 
Hurlock, B, E. 1978. Child Development (Perkembangan Anak). Terjemahan. USA : Mc. Graw-Hill Inc.

Kalingga vol. 5 No. 1. 2002. Reformasi Hukum Tentang Perlindungan Anak. Jakarta : Pusat Kajian dan Perlindungan Anak (PKPA).

Larry Winecoff H. 1988. Values Education : Concepts And Models. Bandung: PPS UPI Bandung.

Moleong, Lexy J. 2004. Metode Penelitian Kualitatif. Bandung : PT Rosdakarya.

Nasution, S. 2003. Metode Penelitian Naturalistik Kualitatif. Bandung: Tarsito.

Phenix, Philiph H. 1964. Realm of Meaning (a philosophy of the curriculum for general education). New York : Mc Graw-Hill Book Company.

Purnianti, Sri S,M., dan Martini, T, Ni Made. 2002.Analisa Situasi Sistem Peradilan Anak di Indonesia.Jakarta:Fisip UI.

Sanusi, A. 1998. Filsafat IImu, Teori Keilmuan, dan Metode Peneltian (Memungut dan meramu Mutiara-Mutiara yang Tercecer). Bandung : PPS IKIP Bandung.

Sauri, S. 2006. Pendidikan Berbahasa Santun. Bandung : PT. Genesindo.

Surapranata, S. dan Hatta, M 2004. Penilian Portofolio Implementasi Kurikulum 2004. Bandung: PT. Rosdakarya. 
Susanto, Astrid S. 1977. Pengantar Sosiologi dan Perubahan Sosial. Bandung : Bina Cipta.

Undang- Undang Republik Indonesia Nomor 23 tahun 2003. Sistem Pendidikan Nasional. Jakarta: Biro Hukum dan Organisasi Sekjen Depdiknas. 